\title{
SEVDAH CELEBRITIES NARRATE SEVDALINKA \\ POLITICAL (SELF-)CONTEXTUALIZATION OF SEVDALINKA \\ PERFORMERS IN BOSNIA-HERZEGOVINA
}

\section{MIHA KOZOROG AND ALENKA BARTULOVIĆ}

The article explores sevdalinka as regional musical genre that represents contradictory ideological positions. The focus is on the various celebrities' discourses with obvious political connotations that have been productive in the making of sevdalinka in past and present Bosnian-Herzegovinian contexts.

Keywords: sevdalinka, Bosnia and Herzegovina, celebrities, music, discourses, nationalism, antinationalism, worldmusic, Yugoslavia
$V$ članku avtorja razkrivata nasprotujoče si ideoloske pozicije, kakor se zrcalijo v regionalnem glasbenem žanru - sevdalinki. V središce zanimanja postavljata različne diskurze zvezdnikov, $v$ katerih je mogoče razbrati očitne politične konotacije, saj so zvezdniki bistveno sooblikovali sevdalinko, in sicer tako v bosansko-hercegovski preteklosti kot v sodobnosti.

Ključne besede: sevdalinka, Bosna in Hercegovina, zvezdniki, diskurzi, nacionalizem, antinacionalizem, glasbe sveta, Jugoslavija

\section{INTRODUCTION}

In the academic discussion of celebrity, it is commonplace to argue that some persons are justifiably awarded with public attention and praise, but that there are also those that attract such attention groundlessly. So explains the essayist Joseph Epstein: fame is "something one earns - through talent or achievement of one kind or another"; it is something "based on true achievement" in contrast to "celebrity on broadcasting that achievement, or inventing something that, if not scrutinized too closely, might pass for achievement" (2005: 9). In Epstein's explanation, celebrity-in contrast to fame-is not earned, but boosted by proclaiming an achievement. In addition, it is commonly proposed that this distinction can be historicized. Daniel J. Boorstin is already known for his definition of celebrity as "a person who is known for his [sic] well-knownness" (1992: 57); however, Boorstin added that in the distant past true heroes existed whose achievements were "real" (1992: 61). Chris Rojek, likewise, explains that celebrity has historically emerged with the rise of public culture, the mass media, democratization of society, the decline in organized religion, the commodification of everyday life, and the transfer of cultural capital from royalty to selfmade men and women: "As modern society developed, celebrities have filled the absence created by the decay in the popular belief in the divine right of kings, and the death of God" (2001: 13). Similarly, Fred Inglis differentiates "honour and fame from glamour and celebrity," the latter being an epiphenomenon of "urban democracy, the two-hundred-year expansion of its media of communication, together with the radical individualisation of 
the modern sensibility" (2010: 5). Moreover, Ellis Cashmore (2006) proposes an evolution from notability based on genuine mastering of certain cultural practice to instant fame that one obtains, for example, by exposing his or her own privacy, which now makes it possible for almost anyone with access to modern technology to attract the attention of anonymous strangers.

We agree that "instant celebrities" (Podjed 2013) and "micro-celebrities" (Marwick 2013), whose fame is based on (largely internet-)mediated alluring representations of their privacy and business, frequent the contemporary daily lives of capitalist modernity, and that historically the evolution of communication media has been changing the conditions of fame. However, at least in our society, it is debatable what counts as a "true" achievement and what only counts as a "boosted" one. Usually, certain people admire things that others repudiate as worthless, whereas many are not even aware of their existence. In addition, public recognition of something, and thus someone's fame, is not equally distributed in society because it is a result of unevenly positioned judgments, which are based on a variety of sociocultural tastes and their hierarchies (Bourdieu 1984). Judging includes both the assessment of an "achievement" and the assessment of assessments of that "achievement." Think of music, which is the topic of this article: you might like the songs, but you disregard the tumult around the singer; consequently, you might turn down the song or remain ambivalent about it. Various feelings and public meanings thus assemble around that song, usually unequally positioned in cultural hierarchies.

Judgments that establish "celebrities" are made in (and are making) different-and sometimes detached- "fields" of cultural (re)production (Bourdieu 1984). These underlie very diverse social milieus, which can live alongside one another. For example, the nextdoor kid might tell you that—-as everyone else knows"—one singer is excellent. However, because you have recently been too busy with your job and detached from popular culture, you hear of the youth idol for the first time. You even miss whether the singer is glorified by millions of people or only by a small niche audience attached to a particular niche media (cf. Marwick 2013: 113). One should acknowledge that "famous" or "celebrity" is not a precise description. Contradictory judgments about what is good or bad, priceless or worthless, and right or wrong spring up side by side, as we present in greater detail with the case of sevdalinka, a regional musical genre that is nowadays also judged through political issues in Bosnia-Herzegovina.

Parallel worlds of popular music are sometimes dichotomized as "mainstream" versus "alternative" (or "underground") and, already as such (i.e., as exclusivist), are an important platform for making judgments about who deserves and does not deserve to be extolled (Thornton 1995). Simon Frith in Performing Rites (1996) demonstrates how judgments of popular music socially and emotionally construct people's own identities and the social milieus they participate in. He depicts the power of discourse in creating the value of music - however, not only of music, but of the entire musical worlds that music constitutes and that constitute music. Music itself is only one of many related "layers" that 
people judge when they talk about music because they also judge the performer's behavior, dress and hair, interviews, musical knowledge, and so on; the record company behind the releases, and many other things. However-and this is important-these "layers" carry unequal cultural capital in different musical genres and social milieus: for example, judgments about a classical musician's communication with a concert audience is usually a less important source of capital than it is for a rock musician, whereas for the latter musical education is not really important in comparison to a classical musician. Moreover, values of music geographically vary (cf. Muršič 2013: 144). As regards sevdalinka, it functions as a popular music, exposed to ratings of performance, performers, mainstream/alternative values, and so on; yet, because of its background is in folk music, judgments about "genuine traditions" also play a part. In any case, the mass media, from general to niche (but with different weights for different people), have an important role in molding the statuses of music and performers.

As we have already indicated, our understanding of celebrity is firmly grounded in Bourdieu's model of taste, judgment, and public discourse, which we apply to the case of sevdalinka. ${ }^{1}$ However, the focus of our analysis is not the riches of discourses that have been productive in the making of the genre's celebrities. Instead, we narrow our focus to discourses with obvious political connotations in past and present Bosnian-Herzegovinian contexts. Performers of sevdalinka in Bosnia-Herzegovina have been publicly judged by political messages that they have ascribed to this music. Moreover, as performers they have been publicly perceived as persons with knowledge about sevdalinka, and therefore their narration of it has had a certain public weight, which is why it has been reflected by themselves and by various publics. We therefore review the historical and contemporary discourses on sevdalinka produced by its celebrities. We claim that these discourses have been constitutive for both the musical genre and for certain political struggles in BosniaHerzegovina. In what follows, we present historically positioned discourses_-among which nationalism, internationalism, and antinationalism rank high—that have accompanied the genre of sevdalinka and made its public representatives noteworthy. ${ }^{2}$

1 Celebrities of another regional musical genre partly connected to sevdalinka (cf. Rasmussen 2002) were recently analyzed by Ana Hofman and Polona Sitar (2016). These authors, who focused on female performers and sources of their public power, similarly relied on discourse analysis and investigated the (cultural) capital that celebrities operated with.

2 Our research is designed as an ethnographic study of the transformation of sevdalinka in wartime and postwar Bosnia-Herzegovina and Slovenia. However, by way of studying various written sources about this music, we recognized the outstanding role of various political discourses in its formation. Hence, this article is primarily based on discourse analysis, although our conversations with some of the performers have certainly shaped our arguments. We thank the Slovenian Research Agency for financing the research projects Engaged Past: Social-Anthropological Analysis of Transformations of Popular Music in the Area of Former Yugoslavia (J6-5557) and Heroes and Celebrities in Slovenia and Central Europe (J6-5558), as part of which our research was carried out. 
Sevdalinka or sevdah ${ }^{3}$ is commonly described as Bosnian-Herzegovinian traditional music. However, it is more appropriate to describe it as a regional music. It is a legacy of the Ottoman Empire, in which cultural interchange was common. This is why similarities between traditional music styles exist in various Balkan countries. ${ }^{4}$ Another reason for understanding this as a regional genre is its popularization in royal and socialist Yugoslavia, which largely took place outside Bosnia-Herzegovina. In fact, there is no single sevdalinka because in different historical eras different musical forms called sevdalinka (co)existed.

The mere fact that this article focuses on Bosnia-Herzegovina- a country with a turbulent history that endured a bloody war in the early 1990s—-demands a certain historical approach. As a country of several constituent nations (the Serbs, Croats, and Muslims or Bosniaks ${ }^{5}$ ), its history and present were regularly explained in terms of ethno-nationalism, state formation, and more recently and less often also in terms of antinationalism (Bartulović 2013). The questions of nation and nationalism, as well as attempts to escape from ethnic ghosts, also have an important shaping effect on the social worlds of sevdalinka.

\section{CONTRASTING HISTORICAL SEVDAH CELEBRITIES AND FORMS OF POPULAR ETHNIC MUSIC}

This section outlines a few historical contexts in which the mass media and music markets influenced the celebrity statuses of sevdalinka performers in various ways. Until the late nineteenth century, the folk music of this part of the world had no means to disseminate cultural products. Because we understand the latter as a condition of modern celebrity, we consider the turn of the century, with the advancement of new technologies and new musicrelated values, to be the era of the beginning of sevdah celebrity. Namely, by the early 1900 s "phonographs and gramophones were relatively well known in the urban settlements of Bosnia-Herzegovina" (Pennanen 2007: 110), ${ }^{6}$ which stimulated the emerging international music industry to create a local record market. To implant the impetus in this local market, recordings by local musicians, who would play familiar music to the local audience, were

3 Sevdah is also called a specific emotion of yearning, usually described as the essence of this music.

4 A well-known example of this phenomenon involves the sevdalinka song "Ruse kose curo imaš" 'Girl, You Have Fair Hair' (also known as "Anadolka” 'Anatolian Girl' in Bosnia-Herzegovina), originally an Ottoman piece, and a number of other songs with a similar melody from a number of Balkan countries (Buchanan 2007).

5 Muslim was an official ethnic/national denomination in socialist Yugoslavia, later replaced by the term Bosniak.

6 After the introduction of the gramophone in the 1890 s, its popularization by the press and merchants was instant and powerful (cf. Kunej 2014). 
crucial (Pennanen 2007). In Bosnia-Herzegovina, these musicians_-among other forms of music_-performed the music that was just starting to be recognized as sevdalinka. ${ }^{7}$

Later on, in the twentieth century, the media for distributing music and cultivating music-related values changed several times. In addition, market conditions were also shifting, very much in relation to political changes. Briefly speaking, before the First World War, popular ethnic music and the market for it were created, which after the war established a few international music stars. After the Second World War, in socialist Yugoslavia, the status of popular ethnic music was renegotiated to suit the multiethnic state's recognition of cultural diversity and reification of the cultural specificity of its federal components. Furthermore, with the breakup of Yugoslavia, the conditions for recognizing popular ethnic music changed again. In this period, sevdalinka gained a clear designation as BosnianHerzegovinian music and was instrumental in the wartime and postwar nation-building process. At the same time, however, it also gained international recognition in the specific market of "world music."

In the twentieth century, therefore, sevdalinka passed through a number of sociopolitical contexts. This was not a linear and univocal process. However, for the sake of clarity, we identify a few historical contexts and historically shaped discourses about sevdalinka step by step.

The first time when music in Bosnia-Herzegovina was produced for commercial purposes was when the territory was annexed by Austria-Hungary (in 1908). Like many aspects of life in the empire, music was also highly regulated and supervised (Pennanen 2007). At the same time, the empire did not suffocate cultural and religious traditions in its territories; instead, it helped (re)invent and exploit them. It is not surprising, therefore, that the state allowed several international record companies, which "were feverishly building up separate repertoires for major nationalities and ethnic groups of the world in order to conquer new market areas" (Pennanen 2007: 112) in the early 1900s, to participate in recording the folk music repertoire in Bosnia-Herzegovina too. The ethnomusicologist Risto Pekka Pennanen (2007) neatly demonstrates how this task, in particular the recording procedure with local musicians from the country, was carried out by the Gramophone Company. The company's endeavor was to create a fresh record market in Bosnia-Herzegovina and neighboring countries. Its method was to send recording engineers to the country where a new market was being prepared, find locally acknowledged musicians, record them, and put their music on records, which were intended to sell primarily in that country. Clearly, because the engineers relied on local information about quality musicians and "good music," these releases strongly reflect the contemporary local musical tastes, judgments, and public opinion about performers deserving celebrity status. As Pennanen's research demonstrates, in 1907 and 1908 several musicians were recorded in this way in Sarajevo, and offered on records in the Gramophone Company's catalogues in 1908 and 1909.

\footnotetext{
Before the end of the nineteenth century, the word sevdalinka is not documented in Bosnia-Herzegovina.
} 
The company's catalogues were defined ethnically; that is, by the "ethnic origin" of the music on the records. The catalogues offered Croatian, Bosnian, Serbian, Montenegrin, and Slovenian music (Pennanen 2007: 144). However, such packaging of ethnically defined musical purity was entangled in the ethnically blurred social milieu of the coffeehouse (kafana); that is, the social institution that dictated the form of sevdalinka at least until the Second World War (see below; cf. Hofman \& Sitar 2016). In this milieu, professional musicians were often ethnically Roma. ${ }^{8}$ As regular performers in coffeehouses, they gained public admiration, the attention of the local press, and invitations for recording. Some of them, such as Vaso Stanković (a.k.a. Andolija), a violinist and singer from Serbia, whose career started in Sarajevo (Pennanen 2007: 123), "were celebrated across the borders in the northern South Slavic lands before the First World War" (Pennanen 2007: 108). Regardless of the border between Austro-Hungary and the Kingdom of Serbia, music was shared regionally, which was often the merit of professional Roma musicians and the institution of the coffeehouse.

After the First World War, when Bosnia-Herzegovina became part of the Kingdom of Serbs, Croats, and Slovenes, the market for popular ethnic music was expanding, which also happened with the support of displaced persons and the economic diaspora (cf. Kunej \& Kunej 2016). In this newly composed world, some performers of ethnic styles were attaining the status of international stars. According to Pennanen, the style of recorded sevdalinka in this period changed in comparison to the prewar style; it "became more Westernised in terms of singing style, harmonisation and instrumentation, and the older style became increasingly unfashionable" (2007: 142).

In the 1920s, the singer Sofka Nikolić became a star performer of various ethnic styles from the Balkans and beyond (Šeper [no year]), including sevdalinka. ${ }^{9}$ Specifications on her records indicate the language in which songs were sung, and the description narodna (folk song) is sometimes added. Sofka and her husband, the violinist and bandleader of a popular Gypsy orchestra, Paja Nikolić, first became well known as performers in coffeehouses in Zvornik and Mostar. Their four years in Mostar have been mythologized as a time in her career when she sang the well-known sevdalinka song "Emina" in front of (or with) its author, the poet Aleksa Šantić. From Mostar, the couple moved to Sarajevo, where people were already enthusiastic about her. From Sarajevo they moved to Belgrade, where they regularly performed at Skadarlija, a bohemian and entertainment quarter of the city. There they were noticed by the local press and benefitted immensely from the interest of Radio Belgrade ${ }^{10}$ in kafanska muzika 'coffeehouse music', which reflects its popularity in the interwar period (Dumnić 2013: 82). Already by the mid-1920s, Sofka

8 In the Kingdom of Yugoslavia, the Roma even strengthened their position through professionalization of music performance (Dumnić 2013: 85).

9 Sevdalinka is an annotated description of some of her hits.

10 Radio Belgrade's predecessor was a telegraph station, which was established in 1924. In 1929 it became a radio station. 
Nikolić had made an international career as a performing and recording singer. Her first record, recorded in Berlin, received a prize for selling well. She was a well-paid artist that could afford to live luxuriously. Her second record was recorded in Paris. Sofka Nikolić's music career ended before the Second World War. She later recalled her celebrity years for a TV show:

In 1926 I had records for [unclearly names the record label]. These records were very remarkable and won the Golden Horseshoe Award. But I know and I've read that [Enrico] Caruso got the Golden Horseshoe Award too, and, well, I received the Golden Horseshoe Award for my records. This was an international recognition. Indeed, at that time I was quite a famous woman and well accepted after those records. I experienced huge fame. A high point I experienced in my life by coming to France, and to Vienna, and to Budapest, and to Sofia, and to Prague, and to America partly, ${ }^{11}$ please. (Nikolić [no year])

The interwar period was also specific with regard to the institutionalization of professional musicians. They established professional organizations with strict membership rules, through which they tried to regulate musical performances in coffeehouses, which were the main source of their income. As Marija Dumnić notes, the battle for control over coffeehouse performances was fought for economic reasons. Interestingly, in these struggles the main targets of criticism were women (singers and musicians), who were regarded as unfair competition (Dumnić 2013: 84-85).

The conclusion that can be drawn about the sevdah celebrities from before the First World War and the interwar period is that they were concerned with the music business, and much less with political agendas accompanying music. Although they were performing popular ethnic music or ethnic styles, which have a clear instrumental value for nationbuilding, it seems that they distanced themselves from such agendas and performed this music because there was a demand for it on the market. For example, Sofka Nikolić did not perform only a single ethnic style, but many of them. Importantly, among the professional musicians there were Roma, who perhaps did not want to become involved in questions of nationalism (cf. Pettan 2001). However, with the passing of the twentieth century, celebrated sevdalinka performers have been increasingly called upon to link their music to the ethnic issue. Moreover, it has also become important to question the ethnicity of performers, as though the music can only be "properly" performed by those with the "right" ethnic background. In other words, the value of ethnicity as cultural capital of performers increased.

Sevdalinka performers taking the stage after the Second World War learned the repertoire and techniques of singing by listening to records. The singer Mileta Janjić recalled that in every Sarajevo coffeehouse a gramophone was playing and children were listening

11 She was probably referring to an alleged book about her by an American author. 
to gramophone records on the street (Karača Beljak 2005: 170). ${ }^{12}$ In postwar Yugoslavia, however, radio replaced the gramophone as the most important means of playing recorded music.

Radio as an instrument of state ideology reinforced two kinds of songs, nurturing two kinds of identification among citizens. First, Partisan and revolutionary songs portraying the Partisan struggle and aspirations for Yugoslav socialism were promoted by radio stations all over the country as part of Yugoslav identity. Second, genres of popular ethnic music, based on selected folk styles and designed as music for mass audiences, were unevenly promoted by radio stations based in different Yugoslav republics. Hence, these radio stations developed and promoted their respective ethnic genres (cf. Sivec 1998). In Bosnia-Herzegovina this genre was sevdalinka.

One of the most admired sevdalinka singers in Yugoslavia was Zaim Imamović. He performed on Radio Sarajevo on the first day it broadcast, on April 10th, 1945. According to a legend, he was so respected as a vocalist that demands for radios in parts of Yugoslavia increased with his popularity: people buying in shops were asking for those radios "that played Zaim." Initially, radio promoted "folk style" sevdalinka; that is, singing without rich instrumentation. When the capacity of Radio Sarajevo broadened, however, songs were also adjusted for richer instrumentation with a radio orchestra (Rasmussen 2002: 34-37).

Nevertheless, the popularity of sevdalinka was not limited to one Yugoslav republic. Although sevdalinka was relatively unknown in Slovenia, it was very popular in Serbia, Croatia, and elsewhere, where it was played on the radio stations of the various Yugoslav republics and performed live at festivals (Petrović 2012: 32). In fact, in this period Radio Belgrade was an influential promoter of a specific improvised style of performance called sevdalijski and of sevdah singing (Rasmussen 2002: 22). Sevdalinka became so popular among its listeners that commentators warned of its destructive influence on "original" Serbian music - and so in the late 1950s a commentator stated that it represented "the ballast of the complicated and confused Muslim world, language, expression, and mentality, which is not ours" (in Rasmussen 2002: 24).

Hence, although on the one hand cultural diversity in Yugoslavia was promoted by and recognized in the ethnic material that more or less efficiently stimulated mutual respect among citizens of different ethnicities, ${ }^{13}$ on the other hand this ethnic material was critically scrutinized by the intellectual elite, which was eager to glorify the "folk core" of the culture of a particular Yugoslav republic. In socialist Bosnia-Herzegovina, many studies of "genuine" sevdalinka were therefore written, with many claiming its Muslim background (cf. Efendić 2015). In this double process of sevdalinka formation, which consisted on the one hand of radio and popular taste, and on the other hand of an intellectual search for

12 Janjić also mentioned that Sofka Nikolićs records were outstanding in this repertoire.

13 In Slovenia, unlike Serbia, sevdalinka oftentimes evoked repulsion. Those that encountered it, mainly young men serving in the army away from Slovenia, described it as howling, not singing. 
folk roots, the most celebrated performers were invited to participate as double agents, both providing entertainment and contributing visions of unspoiled sevdalinka. Respected performers were therefore public personas not only as singers or musicians, but also as connoisseurs of the music's "cultural essence" - as is evident from an interview with the prominent singer Himzo Polovina, given in 1971 to the Bosnian-Herzegovinian Muslim community's journal Preporod: ${ }^{14}$

It's not merely enough to correctly sing a song. There's more. One must penetrate into the inner tissue of a song. A song has layers like a quarry. And any song, even the weakest, has its entrails, just like you and me. One has to know how to penetrate to the entrails. One needs to want to penetrate. When you entertain yourself with this "geology" or such "anatomy," and when you enter a song, but the song enters you, and when you release such a song towards others, then they will also understand that this is not just song as song, but more than that. (Durić 2013)

In Yugoslavia, as has been shown, sevdalinka became a contested ethnic genre. Unlike before the Second World War, it was not primarily shaped in coffeehouses, but at a few republic-level radio stations. Publicly much more exposed, its ethnic and cultural essence was scrutinized by intellectuals and celebrities alike.

\section{HERITAGIZATION OF SEVDALINKA IN POST-YUGOSLAV BOSNIA-HERZEGOVINA}

Until the present, sevdalinka has remained a regional phenomenon. Nevertheless, for its recent (re)conceptualizations, processes in Bosnia-Herzegovina have been essential. In this section we demonstrate that the cultural capital of sevdah celebrities has increasingly resonated with contested political projects in this country.

The war in Bosnia-Herzegovina strengthened specific tendencies regarding the formation of sevdalinka; namely, the state (or civic) Bosnian-Herzegovinian and ethnic Bosniak nationalisms, respectively. One reaction to nationalisms was antinationalism (Bartulović 2013)..$^{15}$ As a coincidence, in the 1990s the "world music" phenomenon emerged in BosniaHerzegovina. Common to these processes was the project of heritagization of sevdalinka; that is, its incorporation into processes of constructing the shape and value of traditions. Through diverse actors, it was variously proclaimed as Bosniak (i.e., ethno-national),

14 Importantly, in 1971 for the first time Muslims were added as the sixth Yugoslav constituent nation to Yugoslav Population Census.

15 For example, the respected sevdah bands Mostar Sevdah Reunion and Halka stressed the multiethnic background of the band members to refer to the multiethnic nature of Bosnia-Herzegovina. This was an antinational stance and/or support of civic nationalism. 
Bosnian-Herzegovinian (i.e., national), and regional heritage (i.e., heritage not limited to one country and rather common to a larger area and its population). ${ }^{16}$ In this context, some new forms of cultural capital for making judgments about sevdalinka and its performers were launched, which invited the performers to comment on them.

As indicated above, already in Yugoslavia there were attempts to identify sevdalinka ethnically. For example, in the first encyclopedic definition from 1969 it appears as a "Muslim urban song," in the Yugoslav literature encyclopedia from 1971 it is assigned to "the ruling Muslim circles . . . in cities," in the oral literature encyclopedia from 1984 it is described as a "Muslim, urban" love song, and in the dictionary of literature terminology from 1985 as a love song "created in Bosnia and Herzegovina, in the urban Muslim environment" (all references cited in Efendić 2015: 99-100). In Yugoslavia, this search for cultural or ethnic "roots" was largely an academic question. In the new circumstances, and especially in relation to competing discourses of ethnically exclusive Bosniak and multiethnic Bosnian-Herzegovinian nationalisms, however, it became both an academic issue (cf. Efendić 2015: 101) and a public one. "Whose songs, whose heritage?" were questions in educational programs (Kurtović 2010), the mass media, and everyday conversations during and after the war.

Under such circumstances of strong politicization of sevdalinka, performers were also judged with regard to acts that counted as one or another form of nationalism. For example, in the context of Bosniak nationalism, acts of religiosity became prominent because Islam was an important part of Bosniak identity formation. It became publicly known, for example, that Emina Zečaj, one of the leading performers of sevdalinka from the 1960s onwards, was a deeply religious person. After performing the Hajj to Mecca, she was repeatedly publicly addressed as hadži-hanuma, a female form of Hajji, among others also by the giant of the postwar heritagization of sevdalinka in Bosnia-Herzegovina, Omer Pobrić, the founder of the Sevdah Institute and Omer Pobrić Foundation (cf. Pobrić 2005). In fact, Zečaj’s acts of religiosity were not intended to remake her celebrity status (she actually avoided publicity and fame), yet her acts were publicly noticed and ascribed meaning, also making her an icon of sevdalinka on the basis of religion.

However, there was another dimension of public recasting of Emina Zečaj, one that can be defined as an inversion of the one just described. Zečaj was discovered by a young generation of intellectuals as a truly authentic performer, also for her rebellious act of breaking with the tradition of keeping women back from singing accompanied by the

16 In the analysis, it can be conceptualized as imperial heritage (cf. Baskar 2015). However, of which empire? Already from the name sevdah, the frequent use of oriental melodies, and the use of instruments like the $s a z$, it could be regarded as the legacy of the Ottomans. However, distinctive musical features of the region were "discovered" and defined only in the late nineteenth and early twentieth centuries, mostly by Austro-Hungarian researchers; for example, Franjo Kuhač, Ivan Zovko, Ludvik Kuba, Matija Murko, and others. Undoubtedly, it is also Yugoslav heritage (see above; Rasmussen 2002; Petrović 2012). 
$s a z \cdot{ }^{17}$ She therefore became an icon of refusal of (religiously supported) patriarchal relations. A discourse of authenticity, ${ }^{18}$ together with narratives about her knowing and living sevdah, started to shape the singer's past and future career. This latter attitude towards Zečaj represents another stream of heritagization of sevdalinka, related to "world music" and antinationalism.

The term "world music" designates an international music market and a field of cultural production following Pierre Bourdieu (Taylor 2014), grounded on the (re)discovery of "culturally authentic" sounds. At the same time, it designates an ideology that promotes ecumenism of "roots" musical expressions from each and every corner of the world (Čolović 2006). As such, it was implemented in antinationalist discourses, which respectively declared sevdalinka as a Bosnian-Herzegovinian (versus ethnic) and regional (versus national) phenomenon with musical parallels around the world.

When the record label Gramofon from Sarajevo decided to record and release the duo of Emina Zečaj and the saz player Mehmed Gribajčević in the early 2000s, it purposefully used the mono technique with minimal production interventions to preserve the "authenticity of the sound." In the introduction to the released CD, ethnomusicologist Vesna Andree-Zaimović presents Zečaj as a genuine collector and preserver of over six hundred songs, devoted to documentary work rather than financial exploitation of tradition, which

is one of the reasons why in the late nineties Zečaj was widely accepted by the international audience. At the time, in the growing tendency named world music, based on folkloric content and idioms, the Bosnian and Herzegovinian music could only fit with one form—sevdalinka that Emina Zečaj performs supported by the saz (Čamil Metiljević and then Mehmed Gribajčević). For those who the language barrier prevents from understanding the poetics of her songs, they are perceived as pure "roots" or "Bosnian blues," as international critics described them sometimes. For us, who can fully enjoy its many layers, they give utmost pleasure. ... Indeed, the core of sevdah can only be utterly presented in a voicesaz combination, ${ }^{19}$ and only if the performers live the melancholy of sevdah with their hearts. (Andree-Zaimović 2003)

This introduction to Zečaj juxtaposes the most regular set of tropes in the discourse on "world music" (cf. Čolović 2006), which stress musical cosmopolitanism as well as

${ }_{17}$ This was perhaps rare, but not nonexistent in the past (cf. Pennanen 2007: 127).

18 Omer Pobrić (2005) observes a fear of the accordion among intellectuals. Pobrić commented on a book about sevdalinka (released in 2004) by the prominent Bosnian-Herzegovinian intellectual Ivan Lovrenović, in which Lovrenović claimed that the accordion killed the culture of sevdah.

19 Precisely the combination of $s a z$ and voice was previously unattractive for radio audiences. It was introduced in the program of Radio Sarajevo during the war in the 1990s by the music editor and ethnomusicologist Tamara Karača Beljak (p.c.). 
allegedly complete detachment of performers from ideologies and economic calculation. Yet, paradoxically, this discourse functions as excessively instrumental for a nationalist project. Namely, sevdalinka, objectified in a particular celebrity, simultaneously represents cultural "roots" and supposedly a universal feeling of blues. ${ }^{20}$ In addition, it is claimed that the feeling of sevdah is a cultural essence, which can only be expressed by exceptional, truly devoted performers, who not only know it, but live it in a respectful way. Furthermore, it is claimed that sevdah can only be felt by a certain "us"; that is, those that are culturally equipped to dig through its layers, although it can, with its "pureness," also reach "outsiders." This paradox of "world music" cosmopolitanism, which can smoothly slip into parochialism, was illustrated by Ivan Čolović:

The magic sound, which can make happy anyone, which can help anyone "find himself or herself," is at the center of narration on world music. When this strengthening sound of authentic music is offered to audiences in Western countries, then they are more or less openly warned that at home they don't have such a cure. (2006: 264)

As Zečaj's case demonstrates, on different grounds activists connected this performer with an ethnic project on the one hand and an antinationalist and allegedly cosmopolitan one on the other. As is clear from this case, a variety of competing and contesting heritagization processes coexisted in the recent history of Bosnia-Herzegovina, which have launched different measures, not only musical ones, for valuing music and performers.

Nevertheless, the antinationalist attempt contains a specific feature, which we want to point out. In post-Yugoslav Bosnia-Herzegovina, sevdalinka has largely become a domain of young "urbanites"; that is, highly educated trendsetting performers and commentators that oppose ethnic divisions between citizens. As the ethnomusicologist Andree-Zaimović has noted, for them sevdalinka represents the "paradigm of a refined, urban Bosnia-Herzegovina” (in Andree 2009) and a means to confront heritagization processes on an ethnic basis. However, because sevdalinka was historically connected with music processes in Bosnia-Herzegovina, an acknowledgement of its ethnic background seems unavoidable. This is especially the case in the context of "world music"-which functions as an important source of cultural capital for these young intellectuals-because the market demands packaging a local music for an international audience by exposing

20 In the context of "world music," authenticity does not necessarily mean recasting "roots." It is in fact more common to praise "authentic hybrids." Perhaps this is so because the weapon of the antinationalist cultural elite, fighting against ethnic purity, is precisely "hybridity" (Čolović 2006: 294). Yet not every hybrid is acceptable, only those that correspond to a specific taste of a specific sociocultural stratum of people acquainted with current art and fashion trends. A welcome hybrid is thus, for example, the electronic remix of Emina Zečaj by Adi Lukovac, whereas an unwelcome hybrid would be, for example, the combination of voice and an accordion or synthesizer. 
its "roots." For this reason, standards of "world music" have functioned as a trap for many recent performers, whose visions of sevdalinka have easily been instrumentalized by nation-building projects. For example, Amira Medunjanin, known also as "Bosnia's Billie Holiday," has stated that her artistic goal is "to create a 'trademark' of spirituality of Bosnia-Herzegovina through its eternal exceptional cultural richness"; these words were reprinted by the Sevdah Art House (Art kuća sevdaha; Kuća sevdaha [no date]: 26), one of the central, state-created institutions for heritagization of sevdalinka. Hence, although "world music" sevdalinka performers are mainly antinationalists (especially with regard to ethnicity), they have nevertheless helped heritagize sevdalinka in national terms (with regard to the state). As internationally successful artists, they contain a unique ideological value in the state faced with tremendous political, economic, and constitutive problems: they perform music that citizens perceive as "theirs" and at the same time make "global" music world acquainted with it.

However, the "world music" sevdah celebrities are also the ones that most cleverly reflect on heritagization processes in the country and political value of music. So let us finish this essay with an analysis of their knowledge and politics.

\section{THE KNOWLEDGE AND POLITICS OF CONTEMPORARY SEVDAH CELEBRITIES}

Although many have tried to explain the essence of sevdalinka, they have regularly failed. This was noticed by Damir Imamović, an internationally admired sevdalinka performer, who urges scrutinized investigation of the genre. Imamović is probably the most devotedat least among performers - to the mission of explaining sevdalinka, although he has not been alone. This recent urge is on the one hand part of the aforementioned "world music" discourse, which is erupting definitions about musical traditions to help consumers orientate in the labyrinth of native sounds. On the other hand, however, it has to do with sevdalinka's role of providing the field for political struggle in contemporary Bosnia-Herzegovina. Sevdalinka has become laden with nationalist and antinationalist meanings and is therefore an exceedingly political genre, which encourages its performers to divide myths from "facts."

It is important to answer on which bases Damir Imamović and other celebrities obtain the capability for publicly narrating sevdalinka. The first basis is their knowledge of sevdalinka, which contemporary performers investigate in detail. The second basis, however, is the role of knowledge in the world of celebrity. In general, celebrities are perceived as persons that possess certain knowledge. For their admirers, they know how to live, behave, and dress, which goods to enjoy or ignore, and, last but not least, which values to respect. For this same reason, they are given space in the mass media and have many "followers" in social media. Their words are reproduced by opinion makers and they also find the way to quotidian conversations. 
Apparently, their words weigh more than the words of an average person. It is important to notice that, although celebrities quite often produce idle talk, such talk nevertheless has political implications; that is, an impact on the public worldview and performance. However, because their message is public, and therefore political, celebrities frequently produce thoughtful political messages. In this regard, sevdalinka offers some good examples.

Let us start with Himzo Polovina, a giant of sevdalinka in Yugoslavia. As already mentioned, in 1971 he gave an interview to the Bosnian-Herzegovinian Muslim community's journal Preporod..$^{21}$ In line with this journal and its struggle for Muslims' recognition in Yugoslavia, the celebrity not only commented on his own career and the essence of sevdalinka (see above), but also used sevdalinka to engage in the politics of ethnicity in Yugoslavia:

I was frequently asked to change the original text of a Muslim folk song, especially when typical Muslim titles were in question. Of course, I never agreed to do it, because to change this in our song is intolerable for me; it is absurd. I have the feeling that Muslim feudal titles from the past times appear to many stranger than others that also belong to this region. It looks like they also intrude on some. Interestingly, nobody alive is disturbed when Strahinjić ban, carica Milica, vojvoda Prijezda, barun Trenk, ban Jelačić and so on ${ }^{22}$ are mentioned. But when a Muslim title comes into question, people are at once irritated. On the radio, there are no agas and begs in a song, ${ }^{23}$ but nobody is troubled by playing Alleluia or Ave Maria . . . Interesting, isn't it? (Durić 2013)

Polovina therefore thoughtfully commented on sevdalinka to support the Muslims' cause in Yugoslavia. Today, however, in an entirely different Bosnia-Herzegovina, marked by an abundance of ethno-national and religious discourses, many politically engaged celebrities have chosen a different approach by contextualizing sevdalinka outside nationalist discourses. Damir Imamović ironically commented as follows:

Sevdah was first associated with Turks, then Slavs, then South Slavs, then Serbs, then Serbs of Muslim faith, then Croats, then Croats of Muslim faith, then "muslim" with a small $m$, then Muslims with capital $M$, and so on. (Imamović 2013)

In addition, not only (anti)nationalism, but other topical social struggles have been incorporated in the recent recasting of sevdalinka; for example, LGBT rights. In this regard, Imamović quotes the well-known sevdalinka that says: "Let anyone love whomever one wishes

21 Perhaps it is not redundant to mention that this journal started in 1970 and that Polovina was interviewed by its editor - this indicates the importance of the interview for the journal.

22 This is a list of Serbian and Croatian titles of high-ranking persons.

23 Aga and beg are titles of high-ranking persons during Ottoman rule. 
to love" (neka ljubi ko god koga hoće). ${ }^{24}$ Another rising star, Božo Vrećo, both discursively and bodily discloses his own transsexuality and sexual orientation. His performances are full of ambiguities concerning gender: his voice cannot clearly be classified as male or female, his dress is regularly female dress, and his bodily moves can be described as feminine. Moreover, because of his vocal range, he can sing "female" and "male" (i.e., gendered) texts alike. As a remarkable vocalist, he has been accepted and praised even by more conservative audiences in Bosnia-Herzegovina. Yet, at the same time his acts have also provoked heated political reactions. For example, the Islamic magazine Saffstumbled upon his video for the song "Lejlija," which was written for his mother, in which Vrećo ends up in the arms of a long-haired male model. This was enough for the magazine to condemn him for, as they wrote, "spreading faggotry through sevdalinka" (Širenje... 2015). Commentators at one of the most frequented internet forums in the country have expressed quite diverse opinions about Vrećo; however, it is clear from this source that the more conservative milieu has declared an open fight against the celebrity:

Lobbies that promote homosexuality are not chosing the proper ways or strategies for reaching their goals. ... They could have promoted homosexuality with pop or rock music but, because no all people listen to that kind of music, they have chosen sevdah because everybody loves it. (Božo Vrećo, pederluk i sevdalinka 2015)

In spite of the violent attacks, the artist publicly expresses certain nonchalance, as though he is merely a prototype of celebrity indulgence. Nevertheless, his acts are already inevitably political as acts of celebrity_consider, for example, his message to his Facebook "friends" on International Women's Day:

My dearest, to stay true to myself, I have to have a double wish for today's special day, because this morning the woman in me walked around my apartment with voluminous hair, ... preparing coffee for two and waiting with hurmašica ${ }^{25}$ for my Omer, ${ }^{26}$ longing for his attention. . . . This is why I know that you just can't wait for your beloved to arrive and give you that magic flower, kiss you, and hug you .... But at the same time the man in me wants to tell you that you are my adorable muses, my inspiration, you are the ones that I admire, you are the ones who can do everything, you understand me best and you love me with all your heart, and you are the ones that I connect to with the most true love.

24 He spoke about emancipatory role of sevdalinka for LGBT persons in the talk "The Knowledge of Sevdah," delivered at the University of Ljubljana's Faculty of Arts on May 26th, 2015.

25 Hurmašica is a popular dessert in Bosnia-Herzegovina.

26 Omer is a common name in the country. 
Let us draw the line here. If we consider the multiplicity of meanings ascribed to sevdalinka, meanings that rank high in the political and public life of contemporary BosniaHerzegovina, it is evident that sevdalinka has played a visible role in a variety of recent political struggles. To make it a valuable currency for one political purpose or another, it had to be heritagized and its essence defined "in the right terms" by different social agents. The genre has therefore been multiply appropriated and policed. Appropriation of knowledge about sevdalinka has urged performers to come to terms about their own knowledge of it. As already mentioned, one of the most devoted sevdah celebrities on the mission of explaining what sevdalinka "really" is has been Damir Imamović. His explanations are based on his own research: he uses archives, has worked with "old masters" (e.g., Emina Zečaj and Čamil Metiljević), and has reflected on his own family’s musical tradition (i.e., the legacy of his father Nedžad Imamović and grandfather Zaim Imamović; see above). He has distributed his knowledge widely: he blogs, gives lectures, and holds workshops, public discussions, conferences, and exhibitions. ${ }^{27}$ His definitions of sevdalinka move in various directions: he neglects any ethnic appropriation of the genre by stressing the regional background; he acknowledges the role of technologies and early commercial exploitation of local repertoires by international recording companies; he proposes that sevdalinka is a genre of emancipation of the socially marginalized, whatever historical or social context we are talking about; he moreover speaks of a genre that is always open to redefining of its own rules. However, what seems to be the most interesting result of his research is an acknowledgement that definitions of sevdalinka regularly fail—and perhaps he is also not entirely satisfied with his own definitions because he is continuously clarifying the terms about what defines this music. Therefore, one of the directions into which he takes sevdalinka could be interpreted as a denial of any essence in regard to it. However, is this acceptable, because there are songs regularly called sevdalinka? And yet, perhaps he is indeed right that there is nothing unique, nor common to the plethora of songs that appear in this part of the Balkans and are sometimes called sevdalinka. However, not even similar songs could be found in many places around the world.

It seems that we are heading nowhere with this internal dialogue. So, instead of setting arguments pro et contra any essentialization of sevdalinka, let us propose an explanation of Imamovićs alleged denial of an essence in the genre. Because such "essences" could be easily nationalistically exploited and otherwise instrumentalized by the powers that be-which has been the case, as we have shown, even in an antinationalist discourse that naively acknowledges music's "homeland"—a radical antinationalist stance demands erasure of any such essence.

27 For example, he held the exhibition and discussion "Sevdah, The Art of Freedom" at the end of 2015 in Sarajevo. 


\section{REFERENCES}

Andree, Marina. 2009. Sevdah. DVD. Zagreb: Studio Dim.

Andree-Zaimović, Vesna. 2003. Introduction. In: Emina Zečaj, Traditional Bosnian Songs. GCD2001. CD. Sarajevo: Gramofon.

Bartulović, Alenka. 2013. "Nismo vaši!” Antinacionalizem v povojnem Sarajevu. Ljubljana: Znanstvena založba Filozofske fakultete.

Baskar, Bojan. 2015. Nacionalna identiteta kot imperialna zapuščina: Uvod v slovensko etnomitologijo. Ljubljana: Znanstvena založba Filozofske fakultete.

Boorstin, Daniel J. 1992 (1961). The Image: A Guide to Pseudo-Events in America. New York: Vintage.

Bourdieu, Pierre. 1984. Distinctions: A Social Critique of the Judgement of Taste. Cambridge: Harvard University Press.

Božo Vrećo, pederluk i sevdalinka. 2015. Forum Klix ba. Available at http://forum.klix.ba/bozo-vreco-pederluk-i-sevdalinka-p11104445.html, accessed May 10th, 2015.

Buchanan, Donna A. 2007. “Oh, Those Turks!” Music, Politics, and Interculturality in the Balkans and Beyond. In: Donna A. Buchanan (ed.), Balkan Popular Culture and the Ottoman Ecumene: Music, Image, and Regional Political Discourse, pp. 3-56. Lanham, MD: Scarecrow Press.

Cashmore, Ellis. 2006. Celebrity/Culture. New York: Routledge.

Čolović, Ivan. 2006. Etno: priče o muzici sveta na Internetu. Belgrade: Biblioteka XX. vek.

Dumnić, Marija. 2013. Muziciranje i muzičari u kafanama u Beogradu od početka emitovanja programa Radio Beograda do Drugog svjetskog rata. Zbornik Matice Srpske za scenske umetnosti i muziku 49: 77-90.

Durić, Rašid. 2013. Sevdalinka i Himzo Polovina. Behar 103. Available at http://behar.hr/sevdalinka-i-himzo-polovina/\#, accessed February 3rd, 2016.

Efendić, Nirha. 2015. The Sevdalinka as Bosnian Intangible Cultural Heritage: Themes, Motifs, and Poetical Features. Narodna umjetnost 52(1): 97-119.

Epstein, Joseph. 2005. Celebrity Culture. The Hedgehog Review 5(Spring): 7-20.

Frith, Simon. 1996. Performing Rites: On the Value of Popular Music. Cambridge: Harvard University Press.

Hofman, Ana, \& Polona Sitar. 2016. "Buy Me a Silk Skirt Mile”: Celebrity Culture, Gender and Social Positioning in Socialist Yugoslavia. In: Rory Archer, Igor Duda, \& Paul Stubbs (eds.), Social Inequalities and Discontent in Yugoslav Socialism, pp. 155-172. London: Routledge.

Imamović, Damir. 2013. Deset najčešćih zabluda o sevdahu. Available at https://www.youtube.com/ watch? $=$ rgN0dnWETjA, accessed February 4th, 2016.

Inglis, Fred. 2010. A Short History of Celebrity. Princeton, NJ: Princeton University Press.

Karača Beljak, Tamara. 2005. Bosnian Urban Traditional Song in Transformation: From Ludvik Kuba to Electronic Medias. Traditiones 34(1): 165-176.

Kuća sevdaha. No year. Art kuća sevdaha. Sarajevo: Art kuća sevdaha.

Kunej, Drago. 2014. Leto 1908 - začetek diskografije slovenske glasbe? Traditiones 43(2): 51-73.

Kunej, Drago, \& Rebeka Kunej. 2016. Glasba z obeh strain: Gramofonske plošče Matije Arka in Hoyer tria. Ljubljana: Založba ZRC SAZU; Ribnica: Rokodelski center.

Kurtović, Enes. 2010. Djeca pjevaju mitove. Školegijum 1-2: no pagination. 
Marwick, Alice E. 2013. Status Update: Celebrity, Publicity, and Branding in the Social Media Age. New Haven, CT: Yale University Press.

Muršič, Rajko. 2013. Pomembneži v Sloveniji: Velmožje in zvezde v slovenski znanosti in popularni glasbi. In: Božidar Jezernik (ed.), Heroji in slavne osebnosti na Slovenskem, pp. 137-149. Ljubljana: Znanstvena založba Filozofske fakultete Univerze v Ljubljani.

Nikolić, Sofka. No year. A TV statement. Available at https://www.youtube.com/watch?v=_a2f58jfEtk, accessed December 24th, 2015.

Pennanen, Risto Pekka. 2007. Immortalised on Wax: Professional Folk Musicians and Their Gramophone Recordings Made in Sarajevo, 1907 and 1908. In: Božidar Jezernik, Rajko Muršič, \& Alenka Batulović (eds.), Europe and Its Other: Notes on the Balkans, pp. 107-148. Ljubljana: Faculty of Arts, University of Ljubljana.

Petrović, Davor. 2012. Četiri okvira za jednu pesmu: Kratka biografija sevdalinke. Etnološko-antropološke sveske 19(8): 25-46.

Pettan, Svanibor. 2001. Kosovo Roma: Music of the Gypsies from Kosovo. Ljubljana: Nika and Društvo za raziskovanje popularne glasbe.

Pobrić, Omer. 2005. Nije tako Ivane ...: Otvoreno pismo Omera Pobrića Ivanu Lovrenoviću u povodu njegovog predgovora izboru 200 najljepših sevdalinki. Bošnjaci.net (January 3rd). Available at http:// www.bosnjaci.net/prilog.php?pid=21154, accessed January 7th, 2016.

Podjed, Dan. 2013. Konec zgodovine Velikih Mož? Samopromocijske strategije instant zvezde Urške Hočevar Čepin in njihov odsev v politiki. In: Božidar Jezernik (ed.), Heroji in slavne osebnosti na Slovenskem, pp. 151-172. Ljubljana: Znanstvena založba Filozofske fakultete Univerze v Ljubljani.

Rasmussen, Ljerka V. 2002. Newly Composed Folk Music of Yugoslavia. New York: Routledge.

Rojek, Chris. 2001. Celebrity. London: Reaktion Books.

Sivec, Ivan. 1998. Vsi najboljši muzikanti: Del 1: Razvoj narodnozabavne glasbe od začetkov do leta 1973. Mengeš: ICO.

Šeper, Lamija. No date. Sofka Nikolić (1907-1982). In: Moj život je muzika. Radio broadcast. Sarajevo: Radio Federacije Bosne i Hercegovine. Available at https://www.youtube.com/watch?v=6C_SEeszQpk, accessed December 24th, 2015.

Širenje... 2015. Širenje pederizma kroz sevdalinku. Saff (February 2nd). Available at http://saff.ba/sirenje-pederizma-kroz-sevdalinku/, accessed February 4th, 2016.

Taylor, Timothy D. 2014. Fields, Genres, Brands. Culture, Theory and Critique 55(2): 159-174.

Thornton, Sarah. 1995. Club Cultures: Music, Media and Subcultural Capital. Cambridge: Polity Press. 


\section{SEVDAH SLAVNE OSEBNOSTI PRIPOVEDUJEJO SEVDALINKA: POLITIČNA (SAMO-)KONTEKSTUALIZACIJA IZVAJALCEV SEVDALINK V BOSNI IN HERCEGOVINI}

$V$ članku so obravnavane različne ideološke pozicije, ki se zrcalijo v regionalnem glasbenem žanru - sevdalinki. Pretresu dominantnih teoretičnih razumevanj zvezdništva sledi historično zasnovan pregled razburljive zgodovine sevdalink v Bosni in Hercegovini, od konca 19 stoletja, tj. časa avstro-ogrskega vladanja v Bosni in Hercegovini, ko sta pojav množičnih medijev in oblikovanje glasbenega tržišča vplivala na promocijo posamičnih ustvarjalcev in njihovo mednarodno uveljavitev. V sodobnem času ne zasledimo le obnovljenega zanimanja za glasbeni žanr in različne politične prilastitve glasbenih tradicij, temveč tudi preboj sevdalink na mednarodne odre oziroma uvrstitev $v$ žanrsko kategorijo glasb sveta (world-music).

$Z$ analizo različnih diskurzov nekdanjih in sodobnih zvezdnikov, izvajalcev in interpretov sevdalink je mogoče razbrati očitne politične konotacije. Že po 1 svetovni vojni lahko sledimo nekaterim slavnim izvajalkam in izvajalcem, ki so si svoj status prislužili z izvajanjem sevdalink, 2 svetovna vojna in nova socialistična Jugoslavija je sevdalinko uvrstila v svojpolitični program konstrukcije multikulturne države, kjer je vsakemu narodu pripisala svojevrstno glasbeno dediščino; v tem okviru je sevdalinka pripadla Bosni in Hercegovini, oz. natančneje, bosansko-hercegovskim muslimanom. Politična instrumentalizacija žanra je bila najbolj temeljita ob brutalni vojni $v 90$ letih, ko je imela osrednjo vlogo v procesih konstrukcije tako bošnjaškega naroda kot tudi trans-etnične oz. državljanske identitete Bosancev in Hercegovcev.

$V$ vseh življenjskih ciklih sevdalinke so imeli prav izvajalci in izvajalke najpomembnejšo vlogo v reinterpretacijah, ne le performativno-glasbenih, temveč tudi političnih. Prepoznani so bili ne le kot glasbeniki in glasbenice, temveć jih je javnost sprejemala kot prave poznavalce glasbenega žanra in njihove izjave pogosto dojema kot najboljšo pot k poznavanju "bistva" sevdalinke. Ko so se po vojni v Bosni in Hercegovini začeli aktivni procesi dediščinjenja sevdalinke, sta se zvezdniški kulturni kapital in pomen v procesih tolmačenja sevdalink bliskovito povečala. Toda politizacija sevdalinke je vsebovala tudi politično razvrščanje in ocenjevanje izvajalcev. $V$ bosansko-hercegovskem medijskem prostoru imamo tako opraviti ne le z bojem med različnimi javnimi razumevanji sevdalinke in njenih poustvarjalcev, temvec tudi z raznovrstnostjo izjav sodobnih zvezdnikov in zvezdnic. Ti namrec sevdalinko pogosto kontekstualizirajo onkraj dominantnih okvirov ter $v$ javnih nastopih implicitno opozarjajo tudi na obrobna politična vprašanja, kakršno je, na primer, obramba družbene odprtosti in pravic marginaliziranih skupin. Z vstopom novih izvajalcev sevdalink na mednarodni glasbeno tržišče se odpirajo tudi novi konteksti za reinterpretacijo glasbenega žanra in za produkcijo prenovljenih pripovedi o sevdalinkah.

Assist. Prof. Miha Kozorog and Assist. Prof. Alenka Bartulović, Department of Ethnology and Cultural Anthropology, Faculty of Arts, University of Ljubljana, Zavetiška 5, SI-1000 Ljubljana, miha.kozorog@ff-uni-lj.si, alenka.bartulovic@ff.uni-lj.si 